\title{
Immigrants from eastern partnership (EaP) countries in Spain
}

\author{
Lídia Farré ${ }^{1,2}$ and Núria Rodríguez-Planas ${ }^{2,3^{*}}$
}

\author{
* Correspondence: \\ rodriguez-planas@iza.org \\ ${ }^{2}$ Institut d'Anàlisi Econòmica \\ (IAE-CSIC), Bellaterra, Spain \\ ${ }^{3}$ Institute for Labor Studies (IZA), \\ Bonn, Germany \\ Full list of author information is \\ available at the end of the article
}

\begin{abstract}
Most EaP migrants in Spain come from Ukraine, followed by, to a much lesser extent, Moldavia, Armenia, and Georgia. Relative to other migrants, they are those who most recently arrived to Spain. Using data from Spanish Labor Force Survey (LFS) from the years 2000 to 2011, this paper analyzes how their employment situation evolves with time in Spain, the type of sectors they work in, and their welfare use, including unemployment insurance receipt. We find that the employment rate of EaP migrants is similar to that of the natives. This is because although they face an employment penalty upon arrival, they catch up quickly. In addition, we document that EaP migrants, despite their higher educational level, are less likely to work than natives and other migrant groups upon arrival to Spain. However, the initial disadvantage in terms of employment and working conditions dissipates over time. We also find that their use of welfare increases with experience in the country.

JEL codes: J61; J15

Keywords: Immigrant assimilation and Eastern Partnership countries
\end{abstract}

\section{Introduction}

Over the last decade, Spain has experienced many changes. It has gone from being one of the most dynamic European economies, with gross domestic product (GDP) growth of 3.4 percent, to experiencing a major reverse after the international financial crisis of 2007, which burst the Spanish real-state bubble and soared unemployment rate to 24 per cent - the highest level among Organization for Economic Co-operation and Development (OECD) countries. Before the collapse of the Spanish economy, the country received an impressive inflow of immigrants - approximately 500,000 per year between 2002 and 2007 - who were quick to find jobs in the booming economy and to integrate in its society. As Figures 1 and 2 show, the composition of migrants changed over time, with EU-15 migrants being overtaken by South Americans and migrants from the EU enlargement member states. While much is known on how migrants from Africa, Eastern Europe and South America assimilate in Spain, there is no evidence on the experience of migrants from Eastern Partnership (EaP) countries (i.e. Armenia, Azerbaijan, Belarus, Georgia, Moldova, and Ukraine) ${ }^{1}$. Nonetheless, the number of EaP migrants has increased considerably over the last decade. There were as few as 4,000 migrants from EaP countries residing in Spain at the turn of the century, and as many as 127,204 in 2011, representing almost 2 per cent of the total immigrant population. This paper's main objectives are to: (i) evaluate the importance of EaP migrants' inflows and stocks in Spain; (ii) identify EaP

\section{Springer}

C 2014 Farré and Rodríguez-Planas; licensee Springer. This is an open access article distributed under the terms of the Creative Commons Attribution License (http://creativecommons.org/licenses/by/2.0), which permits unrestricted use, distribution, and reproduction in any medium, provided the original work is properly cited. 


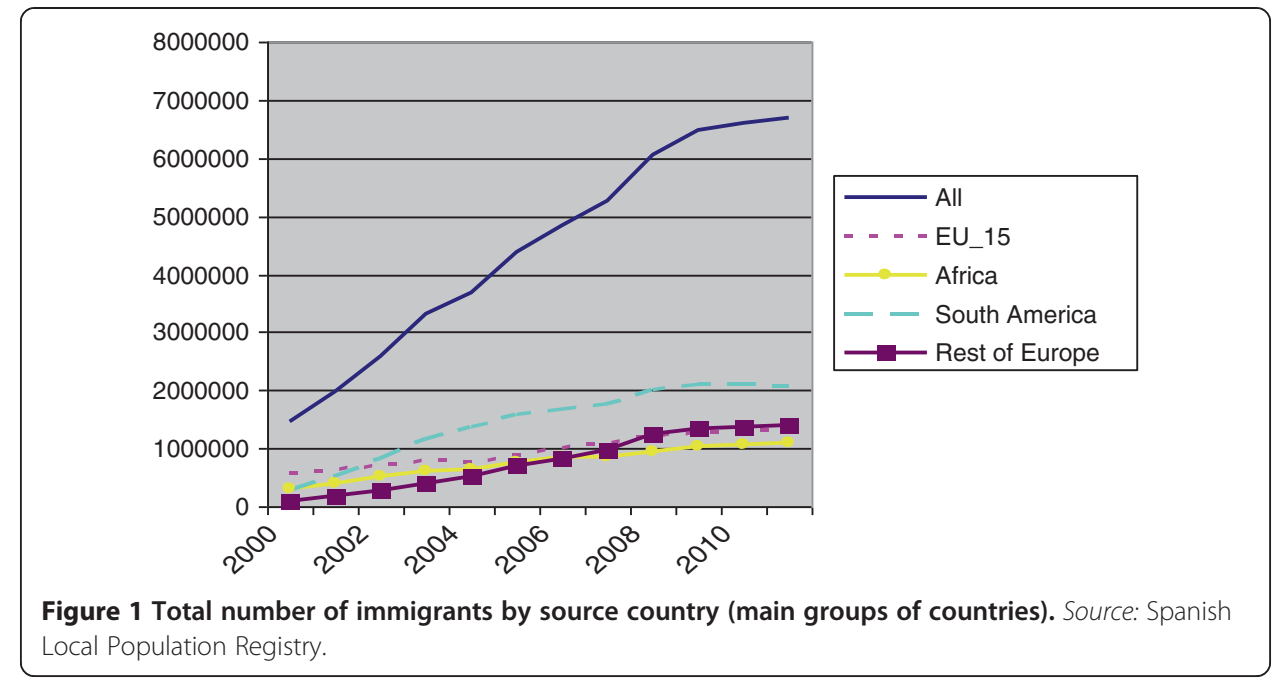

migrants' socio-demographic characteristics and compare them to those of natives and other immigrants; (iii) evaluate the impact of migration from EaP countries on the Spanish labor market and welfare state; and (iv) identify mechanisms to deal with the skill shortages and present migration policies to deal with migrant labor market matching. It is important to highlight that the bulk of EaP immigrants come from Ukraine (i.e. 66\% in 2011). Thus our results and policy implications are largely driven by the behavior of this group.

Our analysis uncovers three important results. First, we find that in contrast with earlier findings on migrants in Spain, EaP migrants are less likely to work than natives and other migrants upon arrival. This result is particularly puzzling because the high education level of EaP migrants relative to both natives and other migrants. A possible explanation for this is that the strong segmentation of the Spanish labor market makes it difficult for highly educated migrant workers to find jobs that match their skills (Alcobendas and Rodríguez-Planas 2009). Since EaP migrants are largely high-skilled workers, their higher reservation wage at arrival is likely to explain their lower employability. As they are high skilled, they may first search for a high-skilled job. As time goes by and they cannot find such type of job, their need for money makes them adapt their expectations and increases their willingness to take less-qualified jobs. In

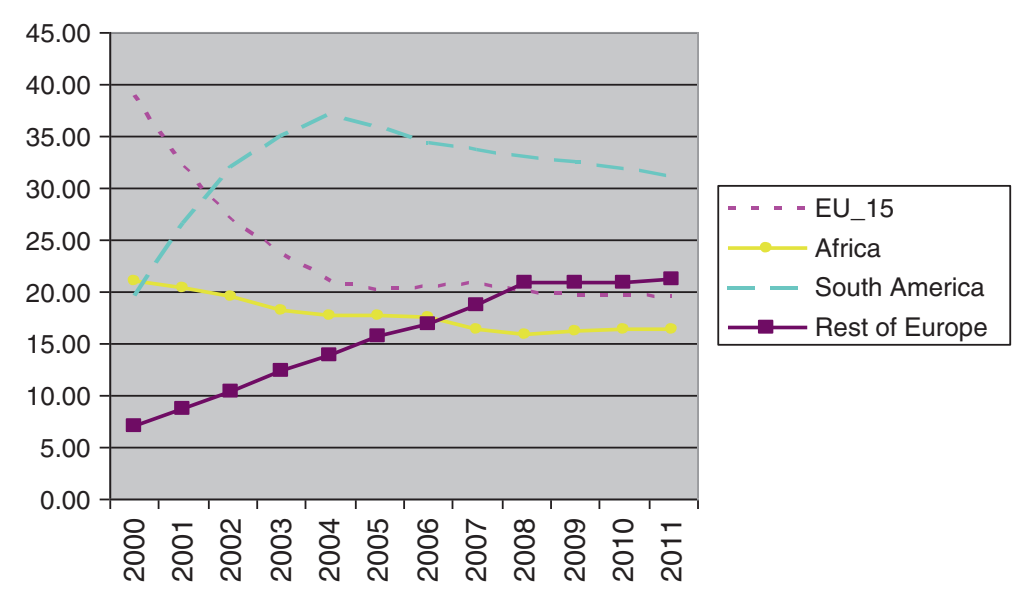

Figure 2 Percentage of immigrants as a share of total immigrants. Source: Spanish Local Population Registry. 
contrast, migrants from other origins, which tend to be lower skilled, have lower reservation wages and thus are more likely to access low-skilled jobs (for which there was an excess supply prior to the real-estate bubble burst in 2007). An alternative and complementary explanation for the difficult labor market integration of high-skilled EaP immigrants in Spain is that they face difficulties obtaining Spanish recognition and professional accreditation for their college or professional degrees. Our estimates indicate that the employment gap with respect to natives dissipates after 10 years in the country, while employment differences between EaP and immigrants of other origins disappear after 5 years.

Second, a common finding in Spain is that immigrants are much more likely to be over-educated than similar natives (Fernández and Ortega 2008; Alcobendas and Rodríguez-Planas 2009). Like these authors, we find that EaP migrants are more overeducated than natives and other immigrants. We also find that EaP migrants work in more vulnerable jobs than natives and other migrants, and that although their employment situation improves over time, convergence is slow. Like other immigrants in Spain, we find that EaP migrants are concentrated in the domestic and construction sector. While EaP women are disproportionately employed in the domestic sector as nannies, nurses and housekeepers (over 50 per cent of them work in this sector), EaP men are mainly employed in the construction sector with about two fifths of EaP men in low-skilled jobs working in this sector.

Third, we find that EaP immigrants assimilate into unemployment benefits over time, and that they do so at a slightly faster rate than other immigrants. This result suggests that most EaP immigrants have come to Spain to work, and since they concentrate in the most vulnerable positions - the most likely to be hit by the recession - they make use of unemployment benefits once they have the right to do so.

The experience of Spain ought to be of interest to policymakers of other Southern European countries that share: (i) common cultural affinities, such as strong family-orientated values associated with a low degree of individualization (Flaquer 2000); (ii) similar socio-economic circumstances, such as rigid labor and financial markets, an important underground economy, low productivity growth and excessive borrowing (Garicano 2008; Andrés 2009); (iii) welfare commonalities, such as the mix of universalistic health-care and education systems with professional pension schemes, the high degree of institutional fragmentation and the lack of an explicit family policy as evidenced by a very limited number of family-friendly social provisions (Ferrera 1996; Guillén 1997); and (iv) a recent preponderance of illegal migration and weak governmental capacity to regulate immigrants' inflows (Castles and Miller 2003; Solé 2004).

The structure of this paper follows. Section 1 evaluates the importance of inflows and stocks of EaP migrants in the Spanish economy. Section 2 identifies EaP migrants' socio-demographic, labor market and welfare use characteristics, and compares them to those of natives and other migrants. Section 3 discusses EaP migrants' legal routes of migration and legal framework in Spain. Section 4 contains the methodological model and the main results on how EaP migrants compare to natives and other migrants in terms of employment and welfare use. Section 5 concludes with a discussion.

\section{Sources}

The main results in this study are derived from a quantitative analysis conducted by the authors. We employ two main data sets: The Spanish Labor Force Survey and the 
Spanish Local Population Registry. The first is a quarterly survey conducted by the Spanish Statistical Institute (INE) and covers about 60,000 households (180,000 individuals) each quarter. It contains detail information on the labor market status and socioeconomic characteristics of the respondents. We restrict the analysis to the year 2000-2011, that correspond to the large immigration episode in Spain. The second data set is the Spanish Local Population Survey conducted also by the Spanish Statistical Office. As we will describe latter in the paper, the main advantage of this administrative data set is that it allows us to quantify the stock of immigrants in the country in a given year.

Along the paper we refer to several studies conducted mainly by Spanish researchers that try to quantify the economic implications of the immigration boom during the 2000s. Other than studies by the two authors of this paper: Farré and Rodriguez-Planas, we also refer to work by Sara de la Rica, Libertad González, Juan Francisco Jimeno, Francesc Ortega, among others.

\section{Inflows and stocks}

To analyze inflows and stocks of migrants in Spain we use the Spanish Local Population Registry, which has the advantage of including undocumented immigrants. As the Spanish welfare system offered until recently free health care and education to all residents including undocumented immigrants - it needs a population registry to keep a record of all individuals who can access this universal welfare ${ }^{2}$. As a consequence, it is in immigrants' best interests to register in the Local Population Registry immediately after arriving in Spain. The registration process does not require proof of legal residence and guarantees full data confidentiality (i.e. the Spanish Government cannot use information in the Local Population Registry to deport undocumented immigrants). Moreover, in the case of an amnesty, the undocumented immigrants can show proof of residence and date of arrival in Spain - a necessary condition to be considered eligible for the amnesty - through their registration in the Local Population Registry. Finally, immigrants are required to update their status every two years, which guarantees the accuracy of the immigrant population in the Spanish Local Population Registry.

Figure 3 plots the inflow of immigrants from the most popular Eastern European countries (Bulgaria, Poland and Rumania). We observe a sharp inflow of Romanians in

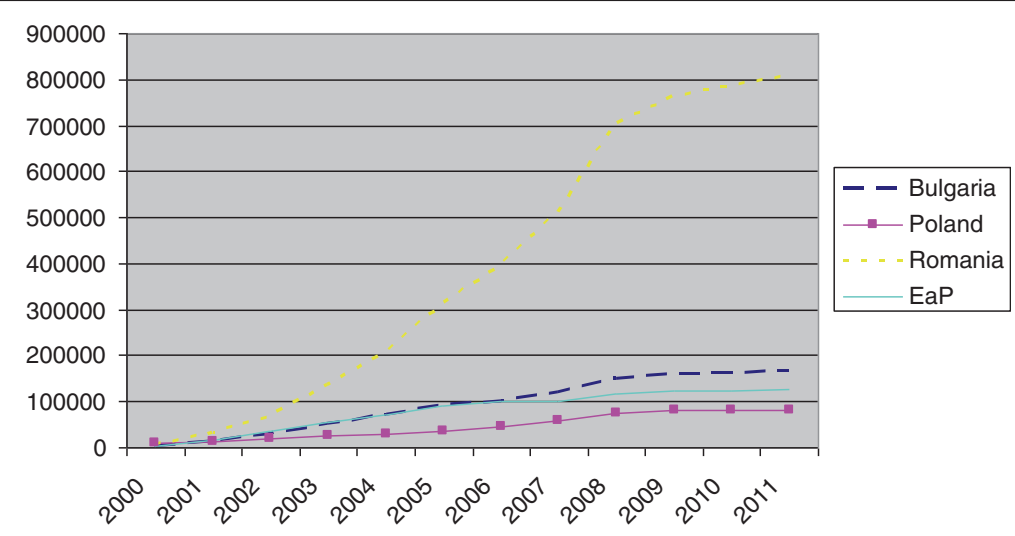

Figure 3 Main Eastern European countries and EaP. Source: Spanish Local Population Registry. 
Spain at the turn of the century. While there were no more than 8,000 Romanians in Spain in 2000 , close to 800,000 of them were living in the country a decade later. Romanians have experienced a particularly interesting status in Spain since 1 January 2007, when their country became part of the European Union. By 2007, Romanians were the second largest group of immigrants in Spain with 11.2 per cent of the share (closely following Moroccans, the first largest group of immigrants). Figure 3 also shows that the inflow of immigrants from EaP countries in Spain resembles that of Bulgarians and Polish immigrants, with an acceleration of the inflow beginning in 2004 and ending after the great recession.

Table 1 compares immigrants from EaP countries with those from the 12 member states which joined the European Union in 2004 and 2007. Data limitations restrict the comparison to the 2000-2008 period. It shows that the number of individuals from the EU enlargement member states living in Spain substantially increased between 2000 and 2008, and that immigrants from EaP countries, as a group, are comparable in magnitude to Bulgarians or Polish.

Figure 4 shows the total number of immigrants in Spain from EaP countries by country of origin. Most come from Ukraine, followed by, to a much lesser extent, Moldova, Armenia and Georgia. We observe few immigrants from Belarus and even fewer from Azerbaijan.

Table 2 shows that, as a group, immigrants from EaP countries accounted for 2 per cent of the immigrant population in Spain in 2011. Again, it is worth noticing that the growing inflow since the beginning of the century halted after the great recession. While the number of immigrants from EaP countries in Spain grew from 4,080 in 2000 to 118,373 in 2008, the increase from 2008 to 2011 was from 124,236 to 127,204. That said, the number of EaP migrants has not decreased after the great recession.

\section{EaP Migrants' socio-demographic characteristics}

Unfortunately, the Spanish Local Population Registry has limited information on immigrants' socio-demographic characteristics and labor force status. To analyze

Table 1 EaP and the 2004 and 2007 EU enlargement

\begin{tabular}{lrrr}
\hline & $\mathbf{2 0 0 0}$ & $\mathbf{2 0 0 4}$ & $\mathbf{2 0 0 8}$ \\
\hline Cyprus & 226 & 234 & 293 \\
Czech Republic & 1,461 & 3,783 & 8,322 \\
Estonia & 111 & 506 & 1,138 \\
Hungary & 1,141 & 2,458 & 6,973 \\
Latvia & 169 & 1,206 & 2,452 \\
Lithuania & 193 & 9,163 & 20,107 \\
Malta & 174 & 187 & 246 \\
Poland & 8,623 & 27,657 & 75,757 \\
Slovakia & 361 & 2,477 & 7,315 \\
Bulgaria & 3,266 & 70,363 & 150,742 \\
Romania & 7,544 & 206,394 & 706,164 \\
EaP & 4,080 & 71,720 & 118,373 \\
\hline
\end{tabular}

Source: Spanish Local Population Registry. 


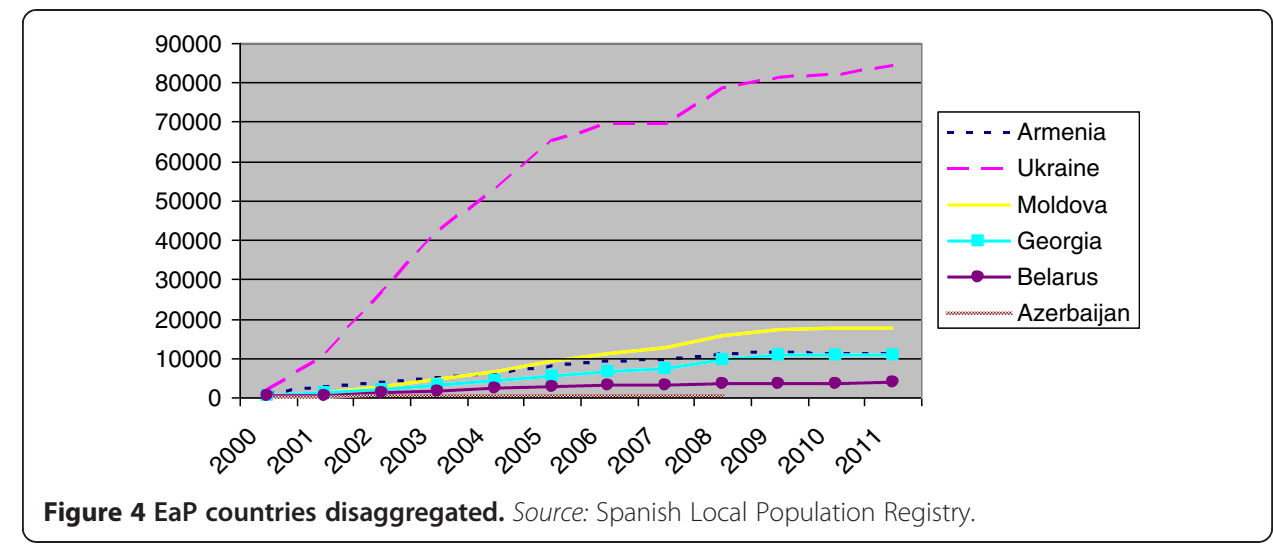

migrants' profile and evaluate their impact in Spain, we focus on data from the second quarter of the Spanish Labor Force Survey (LFS) from the years 2000 to $2011^{3}$. The Spanish LFS gathers information on demographic characteristics (age, years of education, marital status and region of residence), and employment characteristics (work status, occupation and industry). Unfortunately, no information on earnings is available. For immigrants - defined as foreign-born workers who are not Spanish nationals - the LFS collects information on the number of years of residence in Spain and the country of birth. Our analysis focuses on individuals between 16 and 64 years old. We exclude older individuals to avoid complications involving retirement decisions.

One of the strengths of the LFS is that it is supposed to include both legal and illegal immigrants, in contrast to alternative datasets that only cover legal ones, such as the data from the Social Security Records or the Wage Survey Structure. However, the potential under-reporting of illegal immigrants is likely, especially before an amnesty (as the LFS is voluntary, in contrast with the Census, which is mandatory). Similarly, return migration related (or not) to an amnesty may also be worrisome, as both return migration and under-reporting of immigrants may generate deterministic biases in our analysis. However, studies suggest that amnesties ought not to be a major concern in our analysis (see Amuedo-Dorantes and de la Rica 2007; Fernández and Ortega 2008; and Rodríguez-Planas 2013).

Table 3 presents descriptive statistics for natives and immigrants. It also distinguishes migrants' region of origin. Focusing first on EaP migrants, we observe that 56 percent

Table 2 Number of individuals born in the EaP countries living in Spain

\begin{tabular}{lrrrrrr}
\hline & $\mathbf{2 0 0 0}$ & $\mathbf{2 0 0 4}$ & $\mathbf{2 0 0 8}$ & $\mathbf{2 0 0 9}$ & $\mathbf{2 0 1 0}$ & $\mathbf{2 0 1 1}$ \\
\hline Armenia & 1,169 & 6,203 & 10,961 & 11,392 & 11,138 & 10,909 \\
Ukraine & 1,879 & 52,687 & 78,579 & 81,243 & 81,886 & 84,391 \\
Moldova & 190 & 6,333 & 15,534 & 17,174 & 17,457 & 17,405 \\
Georgia & 465 & 4,059 & 9,464 & 10,868 & 10,772 & 10,787 \\
Belarus & 267 & 2,142 & 3,411 & 3,559 & 3,587 & 3,712 \\
Azerbaijan & 110 & 296 & 424 & & & 127,204 \\
Total EaP & 4,080 & 71,720 & 118,373 & 124,236 & 124,840 & $127,67,839$ \\
Total Immigrants & $1,472,458$ & $3,693,806$ & $6,044,528$ & $6,466,278$ & $6,604,181$ & 6,677 \\
EaP/Total Immg & 0.28 & 1.94 & 1.96 & 1.92 & 1.89 & 1.90 \\
\hline Source: Spanish Local Population Registry. & & & & &
\end{tabular}

Source: Spanish Local Population Registry. 
Table 3 Descriptive statistics, natives and immigrants, by region of origin

\begin{tabular}{|c|c|c|c|c|c|c|c|c|c|c|c|c|}
\hline & \multicolumn{2}{|c|}{ Natives } & \multicolumn{2}{|c|}{ All Immigrants } & \multicolumn{2}{|c|}{$\mathrm{EaP}$} & \multicolumn{2}{|c|}{ EU enlargement } & \multicolumn{2}{|c|}{ Africans } & \multicolumn{2}{|c|}{ South Americans } \\
\hline & Men & Women & Men & $\overline{\text { Women }}$ & Men & Women & Men & Women & Men & Women & Men & Women \\
\hline Sample size & 392,983 & 442,021 & 27,078 & 32,437 & 445 & 561 & 3,377 & 3,862 & 6,009 & 5,216 & 10,215 & 14,308 \\
\hline Working & 0.80 & 0.49 & 0.78 & 0.55 & 0.78 & 0.63 & 0.79 & 0.63 & 0.71 & 0.28 & 0.80 & 0.64 \\
\hline Permanent contract & 0.50 & 0.31 & 0.36 & 0.28 & 0.26 & 0.32 & 0.33 & 0.29 & 0.32 & 0.14 & 0.37 & 0.33 \\
\hline Self-employed & 0.19 & 0.07 & 0.14 & 0.06 & 0.05 & 0.02 & 0.07 & 0.02 & 0.10 & 0.03 & 0.12 & 0.05 \\
\hline Welfare recipient & 0.17 & 0.13 & 0.12 & 0.09 & 0.11 & 0.06 & 0.09 & 0.06 & 0.16 & 0.10 & 0.10 & 0.08 \\
\hline Unemployment insurance & 0.05 & 0.05 & 0.08 & 0.05 & 0.10 & 0.05 & 0.08 & 0.05 & 0.11 & 0.05 & 0.09 & 0.06 \\
\hline Disability pension & 0.05 & 0.03 & 0.01 & 0.01 & 0 & 0.01 & 0.01 & 0 & 0.02 & 0.01 & 0.01 & 0.01 \\
\hline Retired pension & 0.07 & 0.02 & 0.02 & 0.01 & 0 & 0 & 0 & 0 & 0.02 & 0 & 0 & 0 \\
\hline Other pension & 0.05 & 0.06 & 0.02 & 0.03 & 0.01 & 0.01 & 0.01 & 0 & 0.03 & 0.04 & 0.01 & 0.02 \\
\hline High-skill occup & 0.15 & 0.12 & 0.13 & 0.08 & 0.03 & 0.04 & 0.02 & 0.02 & 0.09 & 0.07 & 0.12 & 0.08 \\
\hline Medium-skill occup & 0.18 & 0.25 & 0.12 & 0.14 & 0.03 & 0.06 & 0.03 & 0.04 & 0.07 & 0.13 & 0.11 & 0.10 \\
\hline Low-skill occup & 0.67 & 0.63 & 0.75 & 0.78 & 0.94 & 0.90 & 0.95 & 0.94 & 0.84 & 0.80 & 0.77 & 0.82 \\
\hline Male & 0.44 & & 0.46 & & 0.44 & & 0.47 & & 0.54 & & 0.42 & \\
\hline Age & 46.65 & 45.98 & 39.83 & 38.79 & 38.09 & 37.07 & 36.25 & 34.17 & 40.47 & 38.58 & 39.25 & 38.42 \\
\hline Years since migration & & & 11 & 10.72 & 5.88 & 5.40 & 5.34 & 4.87 & 12.78 & 11.83 & 8.54 & 8.49 \\
\hline Age at migration & & & 28.43 & 27.50 & 32.16 & 31.70 & 30.90 & 29.27 & 26.57 & 25.05 & 30.22 & 29.40 \\
\hline Married & 0.84 & 0.80 & 0.72 & 0.68 & 0.79 & 0.70 & 0.72 & 0.68 & 0.79 & 0.81 & 0.67 & 0.62 \\
\hline Primary & 0.29 & 0.32 & 0.22 & 0.21 & 0.09 & 0.08 & 0.12 & 0.13 & 0.47 & 0.56 & 0.16 & 0.16 \\
\hline HS dropouts & 0.29 & 0.28 & 0.21 & 0.20 & 0.11 & 0.13 & 0.16 & 0.19 & 0.19 & 0.18 & 0.21 & 0.21 \\
\hline HS graduates & 0.26 & 0.22 & 0.38 & 0.38 & 0.44 & 0.34 & 0.63 & 0.54 & 0.23 & 0.19 & 0.42 & 0.41 \\
\hline
\end{tabular}


Table 3 Descriptive statistics, natives and immigrants, by region of origin (Continued)

\begin{tabular}{lllllllllrrrr}
\hline College & 0.16 & 0.17 & 0.19 & 0.20 & 0.37 & 0.45 & 0.09 & 0.14 & 0.12 & 0.08 & 0.21 & 0.22 \\
With kids & 0.43 & 0.41 & 0.54 & 0.56 & 0.49 & 0.52 & 0.50 & 0.51 & 0.56 & 0.66 & 0.57 & 0.57 \\
Number of kids & 1.52 & 1.51 & 1.67 & 1.63 & 1.44 & 1.38 & 1.45 & 1.43 & 1.98 & 2 & 1.60 & 1.57 \\
Household size & 3.31 & 3.26 & 3.25 & 3.30 & 3.06 & 3.07 & 3.12 & 3.10 & 3.52 & 3.89 & 3.32 & 3.29 \\
\hline
\end{tabular}

Source: Labor Force Survey 2000-2011.

Notes: The sample is restricted to individuals 16 to 64 years old who are heads of the household or spouses. 
are women. As expected, EaP migrants are younger than the native population. On average, they are about 37 years old - about 9 years younger than natives. EaP migrants are also highly educated, especially when compared to the native population. Over one third of men and close to one half of women have a college degree and only about one fifth of them do not have a high-school degree. In contrast, about 16 per cent of natives have a college degree and almost two thirds have not successfully completed secondary education. While their household structure resembles that of natives in terms of average size, some interesting differences emerge. EaP migrants are less likely to be married and more likely to have children than natives (albeit fewer of them).

Most immigrants come to Spain to work, and EaP migrants are not any different in this respect. Around three quarters of EaP male and two thirds of EaP female migrants in Spain work. Of these, between one quarter of men and one third of women do so under a permanent contract, which guarantees them high severance pay if dismissed. A differential gender pattern emerges: EaP female migrants are 14 percentage points more likely to work than their native counterparts. This higher labor force commitment implies that the share of those who work under a permanent contract is the same as native women (close to one third of those employed in a wage and salary job). In contrast, men do not exhibit a higher employment commitment, and the share of EaP male migrant workers with a permanent contract is, at 26 per cent, half the size of that observed among natives, which is 50 per cent.

Perhaps surprisingly, given their higher education levels, EaP migrants are primarily employed in low-earning occupations. As few as 6 per cent of male and 10 per cent of female EaP migrants work in medium- or high-earning occupations (as shown in Table 3$)^{4}$. Where does the typical EaP immigrant work and how is it different to other migrant groups living in Spain? As EaP and other immigrants are disproportionately over-represented in low-skilled occupations in Spain, Table 4 presents the list of main sectors these immigrants work in and their relative importance. While EaP women are disproportionately employed in the domestic sector as nannies, nurses and housekeepers (56 per cent of them work in this sector), EaP men are mainly employed in the construction sector with 42 per cent of EaP men in low-skilled jobs working in this sector. The domestic sector is also the most common occupation among other female immigrants (51 per cent of those working in low-skill occupations do so in that sector). In contrast, while many women from other ethnic groups work in the

Table 4 Percentage of immigrants workers employed in the most common low skilled occupations

\begin{tabular}{lrrrrrr}
\hline & \multicolumn{2}{c}{ EaP immigrants } & & \multicolumn{2}{c}{ Other immigrants } \\
\cline { 2 - 3 } & Men & Women & & Men & Women \\
\hline Food services (cooks, and waiters) & 0.96 & 20.2 & & 7.3 & 16.4 \\
Sales & 1.92 & 3.71 & & 3.07 & 7.88 \\
Construction & 42.19 & 0 & 35.02 & 0.47 \\
Manufacturing (food preparation, metals, and electrics) & 10.24 & 0 & & 14.19 & 3.49 \\
Domestic services (nannies, nurses, housecleaning) & 2.56 & 56.23 & & 3.7 & 51.43 \\
Agriculture and fishing & 4.15 & 3.71 & & 5.26 & 3.29 \\
Other unskilled jobs (janitors, drivers, warehouse workers) & 17.58 & 4.71 & & 7.31 & 7.21 \\
\hline Source: Labor Force Survey 2000-2011. & & & &
\end{tabular}

Source: Labor Force Survey 2000-2011. 
sales sector (with a share of 8 per cent), the share of EaP female migrants in this sector is limited, probably due to their lower language skills. Finally, both EaP and non-EaP female migrants are also largely represented in the food-services sector (as waiters and cooks) with a share of 20 and 16 per cent, respectively.

Table 3 also indicates that EaP migrants are less likely to be welfare recipients or receive pensions than natives. As Rodríguez-Planas (2013) explains their legal status or insufficient contribution is likely to hamper participation in social programs in Spain a country with a low level of social assistance and a welfare state in which access to pensions is conditioned on having contributed to social security. The only exception is the unemployment insurance (UI) receipt of EaP men, which, at 10 per cent, is double that of native men ${ }^{5}$.

Relative to other migrants, EaP migrants and migrants from the EU enlargement member states arrived most recently to Spain. On average, EaP migrants have been in Spain for a little more than 5 years - about half the average length of African migrants. Most likely this explains the concentration of EaP migrants and those from the EU enlargement member states in low-earning occupations relative to their African and South American counterparts.

\section{Legal routes of migration and legal framework for EaP migrants}

Spain has not had an active policy of attracting immigrants. As early as 1985, it imposed severe restrictions on non-EU foreigners who wanted to establish Spanish residency and citizenship ${ }^{6}$. Beginning in 1993, further tightening took place with tougher restrictions on work and residency permit renewals and the implementation of immigration quotas system, which limited the entry of foreigners to about 30,000 per year. At the turn of the century, Spain updated its immigration legislation, bringing it in line with other European countries.

However, the free entrance of foreigners as tourists together with a lax implementation of immigration laws and several generous amnesties that have granted legal residence to illegal immigrants $(1985,1991,1996,2000,2001$, and 2005) have converted Spain into an attractive destination for immigrants. In fact, the most common way of obtaining legal status in Spain during the past two decades has been through amnesties - often originally entering either illegally or as tourists (see Amuedo-Dorantes and de la Rica 2005, 2008; Dolado and Vázquez 2007; and Izquierdo et al. 2009)7 . Between 1985 and 1991, as many as 150,000 immigrants regularized their status; between 1996 and 2001, a total of 400,000 immigrants did the same; and in the last amnesty, that of 2005 , as many as 550,000 immigrants obtained residence permits.

Today, Spain is part of the Schengen zone a group of countries in Europe which have no internal border controls, so their citizens can cross into the different countries without showing a passport. As EaP countries are not members of the Schengen zone, they are treated as other non-EU migrants. This implies that citizens from EaP countries need a visa to work in Spain in addition to other requirements asked to non-EU citizens, such as a valid passport, no criminal record, private health insurance, documentation to justify the purpose of the trip (visiting friends, work or holiday), a return travel ticket and some financial guarantee (a minimum of $€ 600$ ). As a result of the strict entry requirements, a substantial fraction of non-EU citizens enter 
the country legally through a temporary visa or permit, such as a tourist or a family-visit visa, followed by an overstay - implying that their legal status in the country has expired.

Many researchers have found that networks of migrants from the same country facilitate the arrival and assimilation of migrants into the host country. Unfortunately, the LFS does not ask workers about their networks. However, to explore this we first analyze whether EaP immigrants have clustered in any particular regions in Spain and whether these regions differ to those chosen by other migrants. Table 5 shows the top ten destinations of immigrants in 2002 and 2011 (Panel A displays this information for EaP migrants and Panel B displays this information for other migrants). When the immigration boom started in Spain in the early 2000s, EaP migrants were located in the non-traditional immigrant regions of Albacete, Cuenca and Huelva. While these regions had an immigration share of about 2 per cent in 2002, the concentration of EaP migrants was well above 5 per cent. In contrast, the main destinations of other migrants were Alicante and Balears with an immigrant share of 12 per cent and 11 per cent, respectively.

By comparing the geographical distribution of immigrants in 2002 and 2011, we can also gain some insight on the influence of personal contacts on their migration process. Indeed Albacete and Cuenca are still among EaP migrants' preferred destinations, while those are not popular destinations among other immigrants (i.e. in 2011 the migration

Table 5 Immigrants' preferred destinations, 2002 and 2011

\begin{tabular}{llll}
\hline A. EaP immigrants & & & \\
\hline & $\mathbf{2 0 0 2}$ & $\mathbf{2 0 1 1}$ \\
\hline Albacete & 10.74 & Cantabria & 6.69 \\
Cuenca & 6.53 & Albacete & 4.16 \\
Huelva & 5.08 & Lleida & 4.16 \\
Ciudad Real & 4.92 & Córdoba & 3.39 \\
Cantabria & 4.23 & Valencia & 3.02 \\
Valencia & 4.17 & Cuenca & 2.98 \\
Murcia & 3.24 & La Rioja & 2.94 \\
Lleida & 3.22 & Murcia & 2.84 \\
Huesca & 2.82 & Girona & 2.70 \\
Sevilla & 2.41 & Tarragona & 2.69 \\
\hline B. Other immigrants & & & $\mathbf{2 0 1 1}$ \\
\hline & $\mathbf{2 0 0 2}$ & & 25.75 \\
\hline Alicante & 11.91 & Alicante & 24.33 \\
Baleares & 10.88 & Baleares & 22.89 \\
Melilla & 9.29 & Melilla & 22.50 \\
Girona & 8.98 & Almería & 21.96 \\
Tenerife & 8.25 & Girona & 19.96 \\
Madrid & 8.04 & Tenerife & 19.82 \\
Málaga & 7.83 & Málaga & 19.59 \\
Palmas & 7.31 & Madrid & 18.96 \\
Almería & 7.21 & Lleida & 18.66 \\
Murcia & 6.81 & &
\end{tabular}

Source: Labor Force Survey 2000-2011. 
rate for Albacete is 9 per cent and for Cuenca 13 percent, while the top three receiving regions have a migration rate above 20 per cent).

While networks are likely to have an important role in generating the observed geographical pattern, we cannot rule out that other factors (i.e. regional industry specialization and individual comparative advantages) are also responsible for the distribution of immigrants across Spanish regions.

\section{EaP Migrants' labor market and welfare assimilation in Spain}

\subsection{Empirical specification}

This section examines labor market and welfare assimilation of EaP migrants in Spain. In particular, we analyze whether differences in observable characteristics between EaP migrants and natives, and EaP migrants and other migrants, and explain the observed descriptive differences from the previous section. For this purpose, we estimate the following cross-sectional linear probability model:

$$
\begin{aligned}
Y_{i j t}= & \alpha_{1} X_{i j t}+\alpha_{2} \text { EaP }_{i j t}+\alpha_{3} \text { Female }_{i j t}+\alpha_{4}\left(\text { EaP }_{i j t} x \text { Female }_{i j t}\right)+\alpha_{5} Y S M_{i j t} \\
& +\alpha_{6} Y M_{i j t}^{2}+\delta_{j}+\gamma_{t}+t+t \delta_{j}+\alpha_{7} Z_{j t}+\varepsilon_{i j t}
\end{aligned}
$$

where $i$ indexes the individual, $t$ the LFS year, and $j$ indexes the state. The variable $X_{i j t}$ is a vector of person-specific characteristics, which includes the following socio-demographic controls: age and age squared, marital status, four education dummies (primary education, secondary education but no high-school degree, high-school graduate and college education), household size, number of children in the household and four dummies indicating the age of the children in the household $(0-4,5-9,10-15$ and 16-29 years old). $E a P_{i j t}$ is a dummy variable indicating whether the individual is an EaP immigrant, Female Fijt $_{\text {is }}$ a dummy variable indicating whether the individual is woman, and $\left(E a P_{i j t} \times\right.$ Female $\left._{i j t}\right)$ is an interaction of the two. $Y S M_{i j t}$ and $Y S M_{i j t}^{2}$ control for years since migration to Spain (and its square). The specification also includes State fixed effects $\left(\delta_{j}\right)^{8}$, LFS year fixed effect $\left(\gamma_{t}\right)$, a time trend $(t)$ and a time trend interacted by State fixed effects. $Z_{i j t}$ is a vector describing labor market characteristics (at the province level) and includes the following variables: unemployment rate, share of immigrants, share of immigrants on welfare and share of inactive immigrants at the province level. A normally distributed error term is represented by $\varepsilon_{\mathrm{ijt}}$.

Along the analysis our empirical model is always estimated on three different samples. The first includes EaP immigrants and natives, the second contains EaP immigrants and all other immigrant groups in Spain, and the third limits the comparison to EaP immigrants and immigrants from the 2004 and 2007 EU Enlargement (see Table 1 for a list of the countries included in this group). As EaP migrants most closely resemble EU enlargement migrants, we think this last comparison is particularly relevant to policy.

The LHS variable, $Y_{i j t}$, varies according to the aspect of migrants' assimilation under analysis. For example, when we examine work assimilation, $Y_{i j t}$ is a dummy indicating whether the individual is working at the time of the survey. Other aspects analyzed include dummies for: working under a permanent contract; being self-employed; being unemployed; and receiving cash-welfare benefits - which includes UI benefits, retired pension and other type of pension, including disability pension ${ }^{9}$. In addition, to identify possible skill mismatches and over-qualification, we construct a variable that has the value 1 if the individual works in a low-earning occupation, 2 if in a middle-earning 
occupation and 3 for a high-earning occupation. This last specification is estimated only for individuals working at the time of the survey.

Tables 6, 7, 8, 9, 10, 11 and 12 present the results from these regressions. As mentioned, we are interested in analyzing how EaP migrants compare to natives. Accordingly equation 1 is estimated on a sample of EaP migrants and natives and the results from these estimations are in column 1 of Tables 6, 7, 8, 9, 10, 11 and 12. Columns 2 and 3 repeat the analysis but compare EaP migrants to other migrants living in Spain (in column 2) and to other migrants from EU enlargement member states (in column 3).

Our analysis focuses on the coefficients, $\alpha_{2}$, and $\left(\alpha_{2}+\alpha_{4}\right)$, which capture male and female differences between EaP migrants and: (i) natives (in column 1); (ii) other migrants living in Spain in column 2; and (iii) migrants from EU enlargement member states in column 3, controlling for migrants' year of arrival in Spain. If lower employment- or welfare-participation rates among immigrants are simply due to differences in observable characteristics between EaP migrants and others, the coefficients, $\alpha_{2}$, and $\left(\alpha_{2}+\alpha_{4}\right)$, should not be significantly different from zero when these controls are included in the model.

We also investigate differences in convergence rates in terms of alternative outcomes across immigrant groups. In doing so, we extend the empirical model in equation (1) by including an interaction of the EaP dummy with the years since arrival (YSM and YSM $^{2}$ ). See column (2) and (3) of Tables 6, 7, 8, 9, 10, 11 and 12.

\subsection{Main results}

Below we summaries the main results from Tables $6,7,8,9,10,11$ and $12^{10}$.

\section{EaP migrants are less likely to work than natives and other migrants, although their employment situation improves over time}

Table 6 presents the OLS estimates of the model in equation (1) where the dependent variables is an indicator for whether the respondent is working at the time of the interview. Estimates from column 1 show that on arriving to Spain, EaP male migrants are 32 percentage points less likely to work than their native counterparts (once all observable socio-demographics have been accounted for). Although the employment gap on arrival is smaller between female EaP migrants and natives, it is far from negligible - with EaP women 12 percentage points less likely to work than native women ${ }^{11}$. As the average employment rate for EaP men (women) is 78 (63) per cent, our estimates imply that EaP migrants are 41 (19) per cent less likely to work than their male (female) counterparts when they first arrive. It is important to note that the gap decreases with experience in the country, suggesting that EaP migrants assimilate over time. The employment differential vanishes for men after 11 years and for women after 4 . From this point on it begins to reverse. These patterns (large negative gap upon arrival and relatively fast converge rate over time) are likely to account for the similarity in average employment observed for natives and EaP migrants in the descriptive statistics of Table 3.

The male results contrast with those from Spanish migration literature. For instance, Fernández and Ortega (2008) find that the labor supply of new male immigrants arriving from Eastern Europe and South America is higher than that of similar natives. In addition, they find that while the labor supply increases for South 
Table 6 Employment assimilation

\begin{tabular}{|c|c|c|c|}
\hline & $\begin{array}{l}\text { Relative to } \\
\text { natives } \\
\text { (1) }\end{array}$ & $\begin{array}{l}\text { Relative to other } \\
\text { migrants } \\
\text { (2) }\end{array}$ & $\begin{array}{l}\text { Relative to migrants from } \\
\text { EU enlargement } \\
\text { (3) }\end{array}$ \\
\hline \multirow[t]{2}{*}{$\mathrm{EaP}$} & $-0.321^{* * *}$ & $-0.156^{* * *}$ & $-0.156^{* * *}$ \\
\hline & {$[0.051]$} & {$[0.045]$} & {$[0.048]$} \\
\hline \multirow[t]{2}{*}{ Female } & $-0.303^{* * *}$ & $-0.195^{* * *}$ & $-0.151^{* * *}$ \\
\hline & {$[0.004]$} & {$[0.006]$} & {$[0.014]$} \\
\hline \multirow[t]{2}{*}{ EaP interacted by female } & $0.203^{* * *}$ & $0.097^{* * *}$ & 0.059 \\
\hline & {$[0.036]$} & {$[0.034]$} & {$[0.038]$} \\
\hline \multirow[t]{2}{*}{ Age } & $0.049^{* * *}$ & $0.048^{* * *}$ & $0.042^{* * *}$ \\
\hline & {$[0.001]$} & {$[0.002]$} & {$[0.005]$} \\
\hline \multirow[t]{2}{*}{ Age squared } & $-0.001^{* * *}$ & $-0.001^{* * *}$ & $-0.001^{* * *}$ \\
\hline & {$[0.000]$} & {$[0.000]$} & {$[0.000]$} \\
\hline \multirow[t]{2}{*}{ Years since migration } & $0.029^{* *}$ & $0.006^{* * *}$ & $0.015^{* * *}$ \\
\hline & {$[0.014]$} & {$[0.001]$} & {$[0.005]$} \\
\hline \multirow[t]{2}{*}{ Years since migration squared } & $-0.002^{* *}$ & $-0.000^{* * *}$ & $-0.001^{* *}$ \\
\hline & {$[0.001]$} & {$[0.000]$} & {$[0.000]$} \\
\hline \multirow[t]{2}{*}{ EaP interacted by years since migration } & & $0.031^{* * *}$ & $0.025^{* *}$ \\
\hline & & {$[0.012]$} & [0.013] \\
\hline \multirow[t]{2}{*}{ EaP interacted by years since migration squared } & & $-0.002^{* *}$ & -0.001 \\
\hline & & {$[0.001]$} & {$[0.001]$} \\
\hline \multirow[t]{2}{*}{ Married } & $-0.006^{* * *}$ & $-0.064^{* * *}$ & -0.023 \\
\hline & {$[0.002]$} & {$[0.006]$} & {$[0.015]$} \\
\hline \multirow[t]{2}{*}{ Presence of children } & $0.014^{* * *}$ & $0.023^{* *}$ & 0.007 \\
\hline & {$[0.003]$} & {$[0.010]$} & {$[0.027]$} \\
\hline \multirow[t]{2}{*}{ Household size } & $-0.010^{* * *}$ & $-0.012^{* * *}$ & $-0.022^{* * *}$ \\
\hline & {$[0.001]$} & {$[0.003]$} & {$[0.008]$} \\
\hline \multirow[t]{2}{*}{ Unemployment rate (province) } & $-0.005^{* * *}$ & $-0.010^{* * *}$ & $-0.016^{* * *}$ \\
\hline & {$[0.000]$} & {$[0.001]$} & {$[0.003]$} \\
\hline \multirow[t]{2}{*}{ Share of immigrants (province) } & $0.003^{* * *}$ & $-0.001^{* * *}$ & 0.000 \\
\hline & {$[0.000]$} & {$[0.000]$} & {$[0.001]$} \\
\hline \multirow[t]{2}{*}{ Share of immigrants on welfare (province) } & 0.000 & $-0.002^{* *}$ & -0.002 \\
\hline & {$[0.000]$} & {$[0.001]$} & {$[0.002]$} \\
\hline \multirow[t]{2}{*}{ Immigrant inactivity rate (province) } & $-0.000^{* *}$ & $-0.006^{* * *}$ & $-0.004^{* * *}$ \\
\hline & {$[0.000]$} & {$[0.001]$} & {$[0.002]$} \\
\hline Education dummies & yes & yes & yes \\
\hline Child dummies & yes & yes & yes \\
\hline State dummies & yes & yes & yes \\
\hline Year dummies & yes & yes & yes \\
\hline Observations & 835,996 & 50,081 & 8,168 \\
\hline R-squared & 0.258 & 0.131 & 0.100 \\
\hline
\end{tabular}

Source: Labor Force Survey 2000-2011.

Notes: The dependent variable is an indicator for whether the respondent is employed at the time of the interview. Estimates of a linear probability model reported. Specifications also included a linear trend and a linear trend specific to each region. Samples: Column (1) includes natives and EaP immigrants, Column (2) includes EaP immigrants and all other immigrants, Column (3) includes EaP migrants and immigrants from the 2004 and 2007 EU Enlargement (see Table 2 for a list of countries)

$*^{* * *},{ }^{* *}$ Estimate significantly different from zero at the $90 \%, 95 \%$ level, or $99 \%$ level respectively. 
Table 7 Permanent employment assimilation

\begin{tabular}{|c|c|c|c|}
\hline & $\begin{array}{l}\text { Relative to } \\
\text { natives } \\
\text { (1) }\end{array}$ & $\begin{array}{l}\text { Relative to other } \\
\text { migrants } \\
\text { (2) }\end{array}$ & $\begin{array}{c}\text { Relative to migrants from } \\
\text { EU enlargement } \\
\text { (3) }\end{array}$ \\
\hline \multirow[t]{2}{*}{$\mathrm{EaP}$} & $-0.596^{* * *}$ & $-0.241^{* * *}$ & $-0.134^{* * *}$ \\
\hline & {$[0.040]$} & {$[0.035]$} & {$[0.040]$} \\
\hline \multirow[t]{2}{*}{ Female } & $-0.181^{* * *}$ & $-0.049^{* * *}$ & -0.001 \\
\hline & {$[0.003]$} & {$[0.006]$} & {$[0.015]$} \\
\hline \multirow[t]{2}{*}{ EaP interacted by female } & $0.262^{* * *}$ & $0.113^{* * *}$ & $0.069^{* *}$ \\
\hline & {$[0.033]$} & {$[0.031]$} & {$[0.034]$} \\
\hline \multirow[t]{2}{*}{ Age } & $0.047^{* * *}$ & $0.029 * * *$ & $0.024^{* * *}$ \\
\hline & {$[0.001]$} & {$[0.002]$} & {$[0.005]$} \\
\hline \multirow[t]{2}{*}{ Age squared } & $-0.001^{* * *}$ & $-0.000^{* * *}$ & $-0.000^{* * *}$ \\
\hline & {$[0.000]$} & {$[0.000]$} & {$[0.000]$} \\
\hline \multirow[t]{2}{*}{ Years since migration } & $0.041^{* * *}$ & $0.008^{* * *}$ & $0.041^{* * *}$ \\
\hline & {$[0.010]$} & {$[0.001]$} & {$[0.005]$} \\
\hline \multirow[t]{2}{*}{ Years since migration squared } & $-0.001^{*}$ & $-0.000^{* * *}$ & $-0.002^{* * *}$ \\
\hline & {$[0.001]$} & {$[0.000]$} & {$[0.000]$} \\
\hline \multirow[t]{2}{*}{ EaP interacted by years since migration } & & $0.031^{* * *}$ & 0.003 \\
\hline & & {$[0.009]$} & {$[0.010]$} \\
\hline \multirow[t]{2}{*}{ EaP interacted by years since migration squared } & & -0.001 & 0.000 \\
\hline & & {$[0.001]$} & {$[0.001]$} \\
\hline \multirow[t]{2}{*}{ Married } & $0.015^{* * *}$ & $0.031^{* * *}$ & 0.003 \\
\hline & {$[0.002]$} & {$[0.009]$} & {$[0.010]$} \\
\hline \multirow[t]{2}{*}{ Presence of children } & $0.026^{* * *}$ & $0.028^{* * *}$ & 0.037 \\
\hline & [0.003] & {$[0.009]$} & {$[0.026]$} \\
\hline \multirow[t]{2}{*}{ Household size } & $-0.018^{* * *}$ & -0.002 & -0.011 \\
\hline & {$[0.001]$} & {$[0.003]$} & {$[0.007]$} \\
\hline \multirow[t]{2}{*}{ Unemployment rate (province) } & $-0.001^{*}$ & $-0.005^{* * *}$ & $-0.010^{* * *}$ \\
\hline & {$[0.001]$} & {$[0.001]$} & {$[0.003]$} \\
\hline \multirow[t]{2}{*}{ Share of immigrants (province) } & $0.002^{* * *}$ & $-0.002^{* * *}$ & -0.000 \\
\hline & {$[0.000]$} & {$[0.000]$} & {$[0.001]$} \\
\hline \multirow[t]{2}{*}{ Share of immigrants on welfare (province) } & -0.000 & $-0.003^{* * *}$ & -0.003 \\
\hline & {$[0.000]$} & {$[0.001]$} & {$[0.002]$} \\
\hline \multirow[t]{2}{*}{ Immigrant Inactivity rate (province) } & -0.000 & $-0.001^{*}$ & 0.000 \\
\hline & {$[0.000]$} & {$[0.001]$} & {$[0.001]$} \\
\hline Education dummies & yes & yes & yes \\
\hline Child dummies & yes & yes & yes \\
\hline State dummies & yes & yes & yes \\
\hline Year dummies & yes & yes & yes \\
\hline Observations & 835,996 & 50,081 & 8,168 \\
\hline R-squared & 0.158 & 0.064 & 0.089 \\
\hline
\end{tabular}

Source: Labor Force Survey 2000-2011.

Notes: The dependent variable is an indicator that takes value 1 if the respondent is working under a permanent contract and 0 otherwise. Estimates of a linear probability model reported. The sample include both employed and non-employed workers. Specifications also included a linear trend and a linear trend specific to each region. Samples: Column (1) includes natives and EaP immigrants, Column (2) includes EaP immigrants and all other immigrants, Column (3) includes EaP migrants and immigrants from the 2004 and 2007 EU Enlargement (see Table 2 for a list of countries). $*^{* * *},{ }^{* *}$ Estimate significantly different from zero at the $90 \%, 95 \%$ level, or $99 \%$ level. 
Table 8 Self-employment assimilation

\begin{tabular}{|c|c|c|c|}
\hline & $\begin{array}{l}\text { Relative to } \\
\text { natives } \\
\text { (1) }\end{array}$ & $\begin{array}{l}\text { Relative to other } \\
\text { migrants } \\
\text { (2) }\end{array}$ & $\begin{array}{l}\text { Relative to migrants from } \\
\text { EU enlargement } \\
\text { (3) }\end{array}$ \\
\hline \multirow[t]{2}{*}{$\mathrm{EaP}$} & $-0.115^{* * *}$ & -0.033 & 0.006 \\
\hline & {$[0.023]$} & {$[0.023]$} & {$[0.022]$} \\
\hline \multirow[t]{2}{*}{ Female } & $-0.114^{* * *}$ & $-0.065^{* * *}$ & $-0.044^{* * *}$ \\
\hline & {$[0.001]$} & {$[0.003]$} & {$[0.006]$} \\
\hline \multirow[t]{2}{*}{ EaP interacted by female } & $0.085^{* * *}$ & $0.034^{* *}$ & 0.013 \\
\hline & {$[0.016]$} & {$[0.016]$} & {$[0.017]$} \\
\hline \multirow[t]{2}{*}{ Age } & $0.011^{* * *}$ & $0.002^{*}$ & 0.002 \\
\hline & {$[0.000]$} & {$[0.001]$} & {$[0.003]$} \\
\hline \multirow[t]{2}{*}{ Age squared } & $-0.000^{* * *}$ & -0.000 & -0.000 \\
\hline & {$[0.000]$} & {$[0.000]$} & {$[0.000]$} \\
\hline \multirow[t]{2}{*}{ Years since migration } & -0.005 & $0.009^{* * *}$ & $0.005^{* *}$ \\
\hline & {$[0.004]$} & {$[0.001]$} & {$[0.002]$} \\
\hline \multirow[t]{2}{*}{ Years since migration squared } & 0.000 & $-0.000^{* * *}$ & 0.000 \\
\hline & {$[0.000]$} & {$[0.000]$} & {$[0.000]$} \\
\hline \multirow[t]{2}{*}{ EaP interacted by years since migration } & & $-0.007^{*}$ & -0.005 \\
\hline & & {$[0.004]$} & {$[0.005]$} \\
\hline \multirow[t]{2}{*}{ EaP interacted by years since migration squared } & & 0.000 & 0.000 \\
\hline & & {$[0.000]$} & {$[0.000]$} \\
\hline Education dummies & yes & yes & yes \\
\hline Child dummies & yes & yes & yes \\
\hline State dummies & yes & yes & yes \\
\hline Year dummies & yes & yes & yes \\
\hline Observations & 835,996 & 50,081 & 8,168 \\
\hline R-squared & 0.040 & 0.059 & 0.044 \\
\hline
\end{tabular}

Source: Labor Force Survey 2000-2011.

Notes: The dependent variable is an indicator that takes value 1 if the respondent is self-employed and 0 otherwise. The sample include both employed and non-employed workers. Estimates of a linear probability model reported. Additional controls as in Table 6 and 7 are included (married, presence of children, household size and province controls). Specifications also included a linear trend and a linear trend specific to each region.

Samples: Column (1) includes natives and EaP immigrants, Column (2) includes EaP immigrants and all other immigrants, Column (3) includes EaP migrants and immigrants from the 2004 and 2007 EU Enlargement (see Table 2 for a list of countries).

${ }^{*},{ }^{* *},{ }^{* *}$ Estimate significantly different from zero at the $90 \%, 95 \%$ level, or $99 \%$ level.

Americans over time, it decreases for Eastern European immigrants. When focusing on migrants from the EU enlargement member states, de la Rica (2009) also finds evidence that the employment situation of these immigrants in Spain deteriorates over time. More specifically, she finds that while there is no difference in the probability of working for recent EU-enlargement migrants and natives, non-recent EU-enlargement migrants do worse in terms of employment than their recent counterparts.

How can we reconcile our results with the rest of the literature? First, we find that EaP men fare worse at arrival in terms of employment than other migrants. Results from columns 2 and 3 in Table 6 show that, upon arrival to Spain, EaP male migrants are less likely to work than their migrant counterparts (including those from EU enlargement member states). Second, EaP migrants differ considerably from the average Spanish migrant as they are considerably more educated. More than one third of them 
Table 9 Occupational upgrading

\begin{tabular}{|c|c|c|c|}
\hline & $\begin{array}{l}\text { Relative to } \\
\text { natives } \\
\text { (1) }\end{array}$ & $\begin{array}{l}\text { Relative to other } \\
\text { migrants } \\
\text { (2) }\end{array}$ & $\begin{array}{l}\text { Relative to migrants from } \\
\text { EU enlargement } \\
\text { (3) }\end{array}$ \\
\hline \multirow[t]{2}{*}{$\mathrm{EaP}$} & $-2.509^{* * *}$ & $-1.694^{* * *}$ & -0.553 \\
\hline & {$[0.375]$} & {$[0.364]$} & {$[0.359]$} \\
\hline \multirow[t]{2}{*}{ Female } & $-0.140^{* * *}$ & $-0.244^{* * *}$ & 0.045 \\
\hline & {$[0.006]$} & {$[0.021]$} & {$[0.076]$} \\
\hline \multirow[t]{2}{*}{ EaP interacted by female } & 0.271 & $0.371^{*}$ & 0.079 \\
\hline & {$[0.221]$} & {$[0.221]$} & {$[0.217]$} \\
\hline \multirow[t]{2}{*}{ Age } & $0.010^{* * *}$ & -0.003 & 0.034 \\
\hline & {$[0.002]$} & {$[0.011]$} & {$[0.039]$} \\
\hline \multirow[t]{2}{*}{ Age squared } & $0.000^{*}$ & 0 & 0 \\
\hline & {$[0.000]$} & {$[0.000]$} & {$[0.001]$} \\
\hline \multirow[t]{2}{*}{ Years since migration } & $0.153^{*}$ & $0.042^{* * *}$ & $0.066^{* * *}$ \\
\hline & {$[0.085]$} & {$[0.004]$} & {$[0.022]$} \\
\hline \multirow[t]{2}{*}{ Years since migration squared } & -0.002 & $-0.000^{* * *}$ & 0 \\
\hline & {$[0.004]$} & {$[0.000]$} & {$[0.001]$} \\
\hline \multirow[t]{2}{*}{$\mathrm{EaP}$ interacted by years since migration } & & 0.129 & 0.06 \\
\hline & & {$[0.084]$} & {$[0.082]$} \\
\hline \multirow[t]{2}{*}{ EaP interacted by years since migration squared } & & -0.003 & -0.001 \\
\hline & & {$[0.004]$} & {$[0.004]$} \\
\hline Education dummies & Yes & yes & yes \\
\hline Child dummies & Yes & yes & yes \\
\hline State dummies & Yes & yes & yes \\
\hline Year dummies & Yes & yes & yes \\
\hline Observations & 528,169 & 32,492 & 5,739 \\
\hline R-squared & 0.285 & 0.250 & 0.110 \\
\hline
\end{tabular}

Source: Labor Force Survey 2000-2011.

Notes: The dependent variable takes value 1 if the individual works in a low-earning occupation, 2 if in a middle-earning occupation and 3 for a high-earning occupation. The sample include only workers employed at the time of the survey. Estimates of an ordered probit model are reported. Additional controls as in Table 6 and 7 are included (married, presence of children, household size and province controls). Specifications also included a linear trend and a linear trend specific to each region.

Samples: Column (1) includes natives and EaP immigrants, Column (2) includes EaP immigrants and all other immigrants, Column (3) includes EaP migrants and immigrants from the 2004 and 2007 EU Enlargement (see Table 2 for a list of countries).

$*^{* *},{ }^{* *}$ Estimate significantly different from zero at the $90 \%, 95 \%$ level, or $99 \%$ level respectively.

have a college degree compared to about one tenth of the immigrants the EU enlargement member states and one fifth of South Americans. Moreover, Alcobendas and Rodríguez-Planas (2009) find that, in contrast to low-skilled workers, immigrants with a university degree are over-represented in the "not-working" category compared to their native counterparts. The Spanish labor market is strongly segmented and rigid, making it difficult for high-skilled workers to find jobs that match their skills. Since EaP migrants are largely high-skilled workers, their higher reservation wage at arrival is likely to explain their lower employability. In contrast, migrants from other origins, who tend to be lower skilled, have lower reservation wages and thus are more likely to access low-skill jobs (for which, there was an excess demand prior to the real-estate bubble burst in 2007). According to the estimates in column (2) and (3) the 
Table 10 Welfare residual

\begin{tabular}{|c|c|c|c|}
\hline & $\begin{array}{l}\text { Relative to } \\
\text { natives } \\
\text { (1) }\end{array}$ & $\begin{array}{l}\text { Relative to other } \\
\text { migrants } \\
\text { (2) }\end{array}$ & $\begin{array}{l}\text { Relative to migrants from } \\
\text { EU enlargement } \\
\text { (3) }\end{array}$ \\
\hline \multirow[t]{2}{*}{$\mathrm{EaP}$} & -0.045 & -0.014 & 0.020 \\
\hline & {$[0.031]$} & {$[0.031]$} & {$[0.032]$} \\
\hline \multirow[t]{2}{*}{ Female } & $-0.031^{* * *}$ & $-0.029^{* * *}$ & $-0.023^{* * *}$ \\
\hline & {$[0.001]$} & {$[0.003]$} & {$[0.008]$} \\
\hline \multirow[t]{2}{*}{ EaP interacted by female } & -0.017 & -0.010 & -0.012 \\
\hline & {$[0.026]$} & {$[0.025]$} & {$[0.024]$} \\
\hline \multirow[t]{2}{*}{ Age } & $-0.034^{* * *}$ & $-0.022^{* * *}$ & $-0.013^{* * *}$ \\
\hline & {$[0.000]$} & {$[0.002]$} & {$[0.004]$} \\
\hline \multirow[t]{2}{*}{ Age squared } & $0.000^{* * *}$ & $0.000^{* * *}$ & $0.000^{* * *}$ \\
\hline & {$[0.000]$} & {$[0.000]$} & {$[0.000]$} \\
\hline \multirow[t]{2}{*}{ Years since migration } & $0.021^{* * *}$ & $0.005^{* * *}$ & $0.012^{* * *}$ \\
\hline & {$[0.007]$} & {$[0.001]$} & {$[0.002]$} \\
\hline \multirow[t]{2}{*}{ Years since migration squared } & $-0.001^{* *}$ & $-0.000^{* * *}$ & $-0.000^{* * *}$ \\
\hline & {$[0.000]$} & {$[0.000]$} & {$[0.000]$} \\
\hline \multirow[t]{2}{*}{$\mathrm{EaP}$ interacted by years since migration } & & 0.011 & 0.003 \\
\hline & & {$[0.007]$} & {$[0.008]$} \\
\hline \multirow[t]{2}{*}{ EaP interacted by years since migration squared } & & -0.001 & -0.000 \\
\hline & & {$[0.000]$} & {$[0.000]$} \\
\hline Education dummies & yes & yes & yes \\
\hline Child dummies & yes & yes & yes \\
\hline State dummies & yes & yes & Yes \\
\hline Year dummies & yes & yes & Yes \\
\hline Observations & 835,996 & 50,081 & 8,168 \\
\hline R-squared & 0.143 & 0.093 & 0.078 \\
\hline
\end{tabular}

Source: Labor Force Survey 2000-2011.

Notes: The dependent variable is an indicator for whether the respondent receives cash-welfare benefits (i.e. UI benefits, retired pension and other type of pension, including disability pension). Estimates of a linear probability model reported. Additional controls as in Table 6 and 7 are included (married, presence of children, household size and province controls). Specifications also included a linear trend and a linear trend specific to each region.

Samples: Column (1) includes natives and EaP immigrants, Column (2) includes EaP immigrants and all other immigrants, Column (3) includes EaP migrants and immigrants from the 2004 and 2007 EU Enlargement (see Table 2 for a list of countries).

${ }^{*},{ }^{* *},{ }^{* *}$ Estimate significantly different from zero at the $90 \%, 95 \%$ level, or $99 \%$ level respectively.

initial employment disadvantage with respect to other immigrant groups disappears after 5 years in the country ${ }^{12}$.

EaP migrants are less likely to work under permanent contracts than natives and other migrants, although their employment situation in Spain improves with time relative to natives and most immigrant groups

Table 7 shows the OLS estimates of the model in Equation (1) where the dependent variable is an indicator for whether the respondent is working under a permanent contract and 0 otherwise. The model is estimated on the sample of employed and non-employed workers. The results indicate that EaP migrants are not only less 
Table 11 Unemployment benefits residual

\begin{tabular}{|c|c|c|c|}
\hline & $\begin{array}{l}\text { Relative to } \\
\text { natives } \\
\text { (1) }\end{array}$ & $\begin{array}{l}\text { Relative to other } \\
\text { migrants } \\
\text { (2) }\end{array}$ & $\begin{array}{l}\text { Relative to migrants from } \\
\text { EU enlargement } \\
\text { (3) }\end{array}$ \\
\hline \multirow[t]{2}{*}{$\mathrm{EaP}$} & $-0.045^{*}$ & -0.019 & -0.004 \\
\hline & {$[0.024]$} & {$[0.024]$} & {$[0.025]$} \\
\hline \multirow[t]{2}{*}{ Female } & $-0.002^{* * *}$ & $-0.032^{* * *}$ & $-0.024^{* * *}$ \\
\hline & {$[0.001]$} & {$[0.003]$} & {$[0.008]$} \\
\hline \multirow[t]{2}{*}{ EaP interacted by female } & -0.028 & 0.002 & -0.002 \\
\hline & {$[0.021]$} & {$[0.021]$} & {$[0.021]$} \\
\hline \multirow[t]{2}{*}{ Age } & $-0.003^{* * *}$ & $0.005^{* * *}$ & -0.003 \\
\hline & {$[0.000]$} & {$[0.001]$} & {$[0.003]$} \\
\hline \multirow[t]{2}{*}{ Age squared } & $0.000^{* * *}$ & $-0.000^{* * *}$ & 0.000 \\
\hline & {$[0.000]$} & {$[0.000]$} & {$[0.000]$} \\
\hline \multirow[t]{2}{*}{ Years since migration } & $0.020^{* * *}$ & $0.006^{* * *}$ & $0.012^{* * *}$ \\
\hline & {$[0.006]$} & {$[0.000]$} & {$[0.002]$} \\
\hline \multirow[t]{2}{*}{ Years since migration squared } & $-0.001^{*}$ & $-0.000^{* * *}$ & $-0.000^{* * *}$ \\
\hline & {$[0.000]$} & {$[0.000]$} & {$[0.000]$} \\
\hline \multirow[t]{2}{*}{$\mathrm{EaP}$ interacted by years since migration } & & $0.009^{*}$ & 0.005 \\
\hline & & {$[0.005]$} & {$[0.006]$} \\
\hline \multirow[t]{2}{*}{ EaP interacted by years since migration squared } & & -0.000 & -0.000 \\
\hline & & {$[0.000]$} & {$[0.000]$} \\
\hline Education dummies & yes & yes & yes \\
\hline Child dummies & yes & yes & yes \\
\hline State dummies & yes & yes & yes \\
\hline Year dummies & yes & yes & yes \\
\hline Observations & 835,996 & 50,081 & 8,168 \\
\hline R-squared & 0.027 & 0.055 & 0.074 \\
\hline
\end{tabular}

Source: Labor Force Survey 2000-2011.

Notes: The dependent variable is an indicator for whether the respondent receives unemployment benefits. Estimates of a linear probability model reported. Additional controls as in Table 6 and 7 are included (married, presence of children, household size and province controls). Specifications also included a linear trend and a linear trend specific to each region.

Samples: Column (1) includes natives and EaP immigrants, Column (2) includes EaP immigrants and all other immigrants, Column (3) includes EaP migrants and immigrants from the 2004 and 2007 EU Enlargement (see Table 2 for a list of countries).

${ }^{*},{ }^{* *},{ }^{* *}$ Estimate significantly different from zero at the $90 \%, 95 \%$ level, or $99 \%$ level respectively.

likely to work upon arrival than natives and other migrants, but they are also more likely to work under more vulnerable conditions. Upon arrival, male (female) migrants are 60 (34) percentage points less likely to work under permanent contract than their native counterparts. This gap narrows over time, and takes 15 (8) years for men (women) to vanish, and then reverses. The persistent estimated disadvantage in terms of permanent employment explains the much lower aggregate share of EAP migrants employed under this type of contract (see Table 3).

When comparing EaP migrants' likelihood of working under a permanent contract with other migrants, we observe a gender differential. While EaP men are 24 percentage points less likely to work under permanent contract upon arrival than other migrants, the difference is smaller among women (i.e. 13 percentage points). This differential holds (albeit smaller) when we compare EaP migrants to those from EU enlargement member 
Table 12 Employment assimilation from 2000 to 2007

\begin{tabular}{|c|c|c|c|}
\hline & $\begin{array}{l}\text { Relative to } \\
\text { natives } \\
\text { (1) }\end{array}$ & $\begin{array}{l}\text { Relative to other } \\
\text { migrants } \\
\text { (2) }\end{array}$ & $\begin{array}{l}\text { Relative to migrants from } \\
\text { EU enlargement } \\
\text { (3) }\end{array}$ \\
\hline \multirow[t]{2}{*}{$\mathrm{EaP}$} & $-0.405^{* * *}$ & $-0.198^{* * *}$ & $-0.209^{* * *}$ \\
\hline & {$[0.083]$} & {$[0.075]$} & {$[0.076]$} \\
\hline \multirow[t]{2}{*}{ Female } & $-0.350^{* * *}$ & $-0.261^{* * *}$ & $-0.202^{* * *}$ \\
\hline & {$[0.004]$} & {$[0.008]$} & {$[0.021]$} \\
\hline \multirow[t]{2}{*}{ EaP interacted by female } & $0.174^{* * *}$ & $0.075^{*}$ & 0.033 \\
\hline & {$[0.046]$} & {$[0.043]$} & {$[0.050]$} \\
\hline \multirow[t]{2}{*}{ Age } & $0.047^{* * *}$ & $0.055^{* * *}$ & $0.038^{* * *}$ \\
\hline & {$[0.001]$} & {$[0.003]$} & {$[0.008]$} \\
\hline \multirow[t]{2}{*}{ Age squared } & $-0.001^{* * *}$ & $-0.001^{* * *}$ & $-0.001^{* * *}$ \\
\hline & {$[0.000]$} & {$[0.000]$} & {$[0.000]$} \\
\hline \multirow[t]{2}{*}{ Years since migration } & $0.100^{* * *}$ & $0.005^{* * *}$ & $0.035^{* * *}$ \\
\hline & [0.038] & {$[0.001]$} & {$[0.007]$} \\
\hline \multirow[t]{2}{*}{ Years since migration squared } & $-0.008^{* *}$ & $-0.000^{* *}$ & $-0.002^{* * *}$ \\
\hline & {$[0.004]$} & {$[0.000]$} & {$[0.000]$} \\
\hline \multirow[t]{2}{*}{$\mathrm{EaP}$ interacted by years since migration } & & $0.079^{* *}$ & $0.083^{* *}$ \\
\hline & & {$[0.037]$} & {$[0.036]$} \\
\hline \multirow[t]{2}{*}{ EaP interacted by years since migration squared } & & $-0.006^{*}$ & $-0.008^{* *}$ \\
\hline & & {$[0.004]$} & {$[0.003]$} \\
\hline Education dummies & yes & yes & yes \\
\hline Child dummies & yes & yes & yes \\
\hline State dummies & yes & yes & yes \\
\hline Year dummies & yes & yes & yes \\
\hline Observations & 553,951 & 20,583 & 3,244 \\
\hline R-squared & 0.290 & 0.174 & 0.140 \\
\hline
\end{tabular}

Source: Labor Force Survey 2000-2007.

Notes: The dependent variable is an indicator for whether the respondent is employed at the time of the interview. Estimates of a linear probability model reported. Additional controls as in Table 6 and 7 are included (married, presence of children, household size and province controls). Specifications also included a linear trend and a linear trend specific to each region.

Samples: Column (1) includes natives and EaP immigrants, Column (2) includes EaP immigrants and all other immigrants, Column (3) includes EaP migrants and immigrants from the 2004 and 2007 EU Enlargement (see Table 2 for a list of countries).

${ }^{*},{ }^{* *},{ }^{* *}$ Estimate significantly different from zero at the $90 \%, 95 \%$ level, or $99 \%$ level.

states. However, it is very persistent as the estimates in Table 7 (column 3) do not indicate evidence of convergence over time.

\section{EaP migrants are less likely to be self-employed than natives}

It may be that since they are high-skilled workers, EaP migrants may be more entrepreneurial than natives or other migrants. Table 8 reports the estimates of a model where the dependent variable takes value 1 for self-employed workers and 0 otherwise. Note that the model is estimated on a sample of employed and non-employed workers. The table does not report evidence of a higher entrepreneurial activity among EaP immigrants. Upon arrival, EaP male migrants are 11 percentage points less likely to be self-employed than natives and this differential does not seem to decrease over time. The initial differential 
between EaP female immigrants and natives, though statistically significant, is considerably smaller than that observed among men (i.e. only 3 percentage points). This is likely to be partly explained by the fact that as many as 45 per cent of EaP female migrants are college graduates. We do not observed significant differences in the propensity to be self-employed across different immigrant groups and the pattern remains constant over time.

\section{EaP migrants are over-qualified for their jobs and more so than natives and other migrants}

In addition, to identify possible skill mismatches and over-qualification, we construct a variable that has value 1 if the individual works in a low-earning occupation, 2 if employed in a middle-earning occupation and 3 for a high-earning occupation. Table 9 displays the estimated coefficients of an ordered probit model for the occupational upgrading model. Since the estimated coefficients are those of a non-linear model, to interpret the results we have computed the marginal effects. Accordingly, upon arrival to the country EaP migrants have, on average, a 32 percentage points higher probability of being employed in a low-earning occupation than their native counterparts. In contrast, the average probability of being employed in a middle-earning or highearning occupation is, respectively, 23 and 9 percentage points lower. The initial differential vanishes after 6 to 8 years in the country for low and middle-earning occupations, and after 3 years for high-earning occupations.

Differences in the occupational distribution of EaP immigrants and other immigrant groups are also significant. When compared to all other immigrants, EaP migrants have a 14 percentage points higher probability of being employed in a low-earning occupation, while the probability of employment in a middle or high-earning occupation is, respectively, 9 and 5 percentage points lower. While the magnitude of these differences is small (relative to that with natives), the gap persists over time and only disappears after 10 to 14 years in the country.

Our findings are consistent with previous evidence reporting that EaP migrants are more over-educated than natives and other immigrants. Previous studies also find that the native-immigrant over-education differences are largest for Eastern European immigrants, which are the ones with the highest levels of education. Estimates from column 3 in Table 9 show that there are no over-education differences between EaP and migrants from EU enlargement countries.

Moreover we find that the over-education mismatch between EaP migrants and natives decreases over time, though it takes several years until it disappears. The persistence of this negative effect is consistent with the findings from Fernández and Ortega (2008), which reveal that the over-education gap of male immigrants with comparable natives is unaffected by the number of years since migration. These findings are also in line with Alcobendas and Rodríguez-Planas (2009), who find that the degree of assimilation in Spain is higher the lower their education level. These authors find that high-skilled immigrants are over-represented in the "non-qualified" occupation category, which includes jobs such as, janitors, entry positions in construction work, non-qualified laborers, house-cleaning, child and elderly caring. Section 6 below presents alternative explanations on why immigrants are over-represented in low-qualified occupations (regardless of their educational level) and the lack of upward occupational mobility. 
There is no residual welfare gap between EaP migrants and natives

Table 10 presents the estimates for the model in (1) where the dependent variable is an indicator of whether the respondent receives cash-welfare benefits (i.e. UI benefits, old-age pension and other type of pension, including disability pension) and 0 otherwise. The residual welfare gap between EaP migrants and natives in Spain is a negative (albeit not statistically significant) 4.5 percentage points - shown in column 1 in Table 10. This negative residual welfare gap upon arrival is consistent with the Rodríguez-Planas (2013), who finds that immigrants in Spain are less likely than natives to participate in cash-benefit social programs - even when controlling for observable characteristics ${ }^{13}$. The author concludes that the self-selection of immigrants coming to a relatively ungenerous welfare state (at least in terms of means-tested social programmers) is likely to be a reason for this result.

It is interesting to note that the coefficient in the "years since migration" variable in column 1 of Table 10 is positive and statistically significant. Although, on its own, this estimate may seem to suggest that over time, EaP migrants increase their welfare use relative to similar natives, when information from column 1 in Table 11 is added, it is clear that assimilation into welfare is all driven by UI benefits. This is consistent with Rodríguez-Planas (2013), who finds that there is no assimilation into cash-welfare benefits in Spain (other than UI benefits). This result contrasts with findings from other countries - even ones with traditionally not very generous states, such as the United States.

When comparing EaP welfare use to that of other migrants in Spain, there is no differential in use neither upon arrival nor over time. All groups tend to become more welfare dependent over time, though at a similar rate (see the positive coefficient on years since arrival, while that on the interaction with the $\mathrm{EaP}$ indicator is not statistically significant).

\section{EaP migrants are less likely to receive UI upon arrival than natives, but this differential decreases over time}

Table 11 presents the estimates of the model where the dependent variable is an indicator of whether the individual receives unemployment benefits and 0 otherwise. Column 1 in Table 11 shows that EaP migrants are 4.5 percentage points less likely to receive UI upon arrival in Spain. This result is consistent with the Spanish social security system, which being a defined benefit pay-as-you-go system, conditions receipt and level of unemployment benefits to the worker's labor history (wages and number of years of contribution). When we compare UI receipt between EaP migrants and other migrants upon arrival to Spain, holding all other characteristics constant, we do not find a statistically significant difference (columns 2 and 3 in Table 11).

We find that EaP immigrants assimilate into unemployment benefits with time spent in the new country. Two and a half years after arriving, the difference in UI receipt between EaP migrants and natives disappears and begins to reverse. In contrast, Rodríguez-Planas (2013) finds that it takes between 6 to 8 years in Spain for the difference to vanish when all immigrants (not just $\mathrm{EaP}$ ) are compared to natives. Since EaP immigrants concentrate in the most vulnerable positions, they are the first to be hit by recession. Thus, they use unemployment benefits as a supplement of income once they have the right to do so. This is likely to be part of the explanation for 
the sustained stock of EaP immigrants even after the great recession. Finally, there is some evidence of a faster assimilation into welfare by EaP immigrants as compared to other immigrants, but the differential in converge rates is less than $1 \%$.

\section{Conclusions}

\subsection{Impact of EaP migrants on the receiving country}

The number of EaP migrants in Spain increased from 4,080 in 2000 to 127,204 in 2011. Despite the substantial increase in absolute numbers, this group represented only a 2 per cent of the foreign-born population in 2011. Thus, we do not expect them to have had any important impact on the labor market. Most of the literature on migration finds a small effect (if any) of migration inflows on the labor market prospects (employment and wage) of natives with similar skill levels. This result has also been confirmed for the Spanish case (Carrasco et al. 2008). Given the small size of the EaP migrants as a group we cannot perform any rigorous econometric analysis. However, in light of previous evidence, one should not expect any significant effect from the EaP migrants on the labor market outcomes of natives with similar skill levels.

In contrast, a recent literature has presented evidence of some complementarities between low-skilled immigrants and high-skilled natives. For the Spanish case, Farré et al. (2011) show that the massive inflow of immigrants during the last decade had a positive effect on the labor market participation of high-skilled native women. The authors show that female migration has substantially decreased the price of domestic services. In response to this fall in prices, high-skilled women have hired domestic services and substituted away hours of home production (childcare and housekeeping) by hours of work in the market. The estimates in Farré et al. (2011) indicate that the large inflow of immigrants to Spain between 1999 and 2008 led to a 3-percentage-point increase in the participation rate of highly skilled women with family responsibilities.

As shown in Table 4 EaP female immigrants are disproportionately employed in domestic services. Thus, this group is likely to have contributed to the increase in the labor market participation of native women. The share of EaP women over the immigrant population increased from almost 0 to more than 2 per cent between 1999 and 2008. According to the estimates in Farré et al. (2011), this group would have been responsible for about a 0.06 -percentage-point increase in native female employment (i.e. a 2 per cent of the total increase in native female employment).

Alternatively, one may wonder how the recession is affecting EaP migrants. To explore this, we have re-estimated Table 6, but using only the pre-recession years, that is from 2000 to 2007 (shown in Table 12). When doing so, we observe that, compared to natives, the employment gap is larger during this period. The reduction in the employment gap after including the recessionary years may respond to the increase in the unemployment rate of natives. While the crisis has hit harder those in more vulnerable positions, which tend to be over-represented by immigrants, if natives are less flexible and mobile than immigrants because they have higher reservation wages or stronger roots, they may be strongly affected by the crisis.

How do EaP migrants affect the Spanish pension, health and education systems? It is important to acknowledge that immigrants come to Spain to work and by doing so they contribute to the system. In addition, because the immigration boom is a relatively 
recent process in Spain, very few migrants receive old age pensions as they are still in working age (Muñoz de Bustillo and Antón 2009). This is particularly true of EaP migrants as they are younger than migrants from other origins. Moreover, the Spanish Social Security System is a defined benefit pay-as-you-go system where the pension level depends mainly on the labor history of the worker (wages, number of years of contribution and age of retirement). Thus, even if they were over 65 years old, EaP migrants would not receive old age pension unless they contributed the minimum 15 years required by law. As a consequence, it is likely that immigrants make a positive contribution to the situation of the national pension system.

Moving now to the effects of EaP migrants to the health care system, Muñoz de Bustillo and Antón 2009, analyze immigrants' use of Spanish public health care insurance using data from the 2003 Spanish Health Survey. They find that immigrants incur lower health expenditures than natives, even when controlling for observable characteristics $^{14}$. Finally, Salinas Jiménez and Santín González 2010, estimate that the total direct expenditures accumulated by the Spanish national and regional governments from the school year 2000-2001 to 2006-2007 amount to $€ 2.570$ million Euros, most of which (about 70 percent) have been concentrated in Andalucía, Cataluña and Madrid. As EaP migrants represent 2 percent of all migrants, they have increased the Spanish educational expenditures by no more than $€ 51,4$ million Euros.

\subsection{Reasons for the mismatch between skilled EaP migrants and their low-skilled jobs}

Rodríguez-Planas (2012) discusses potential alternative and (possibly) complementary explanations of why skilled migrants in Spain are concentrated in low-skilled jobs. These explanations would of course also apply to EaP migrants. We summarize them below. The first explanation for why skilled migrants are concentrated in low-skilled jobs is the structural nature of the Spanish economic growth in the last decade, combined with the weak governmental capacity of regulating immigrant inflows. The second is the imperfect transferability of human capital acquired abroad, which implies that the higher the homeland education the greater the gap between the native and the immigrant's human capital. Third, in an economy with a segmented labor market and with a large informal sector as the Spanish economy, it is easier to converge towards the occupational distribution of low-skilled workers, but extremely hard to penetrate the high-skilled labor market. The fourth reason is the need for certification. Several occupations that require high levels of education also require certification in the destination country. This is clearly the case in the Spanish labor market - and not only for architects, physicians or lawyers, but also for electricians and plumbers. A fifth explanation is that immigrants may affect the labor market decisions of natives with different skills through the presence of complementarities. In such case, there would be a shift towards less manual jobs among the native population compared to a shift in the opposite direction for immigrants. Several recent papers have highlighted that native and immigrant workers of similar educational attainment specialize in different occupations and therefore do not compete for the same jobs, explaining the small effect the inflows of immigrants on the wages of the less-educated natives in the U.S. (Gianmarco et al. 2012) as well as in Spain (Carrasco et al. 2008, Alcobendas and Rodríguez-Planas 2009, and Amuedo-Dorantes and de la Rica 2013). 
Finally, prejudicial attitudes leading to discriminatory behavior could also produce lower labor market attainments for member of visible minority groups.

\subsection{Skill shortages and potential for labor market matching with EaP immigration}

Since the great recession, the Spanish economy has suffered a major reverse. The burst of the real-estate bubble, a failing banking system, a lack of liquidity and loans for firms, and a rigid labor market have driven the economy to a double-dip recession within four years. The change of government by the end of 2011 has shifted the social welfare priorities and has changed the regulation so that universal health care is no longer readily available to legal and illegal immigrants. As a consequence the inflow of immigrants has come to a halt, regardless of their nationality. In addition, the soaring unemployment rate is pushing both immigrants and natives to leave the country as employment perspective becomes meager. Within this context, the following two major concerns arise. First, the rising unemployment benefit costs due to very large numbers of people losing their jobs during the current recession; and second, the risk of social exclusion with the well-known medium- to long-term consequences of social and cultural integration of immigrants due to their vulnerable situation and the scarcity of social assistance available in Spain.

How have immigrants coped with the soaring job destruction rates observed in Spain? Because immigrants are concentrated in sectors of the economy that were the most vulnerable during the recession (i.e. construction), and partly because migrants tend to be younger and have less job security than natives, it is likely that they are the first to be laid off. However, the overall stock of (EaP) migrants has not decreased as much as expected given that the unemployment rate in Spain has soared to over 25 percent. Indeed, as of 2011, we have not observed the massive return of immigrants to their country of origin even after losing their jobs (Lopez 2011).

As a reaction to the crisis, the Spanish authorities introduced the Plan de Retorno Voluntario - a pay-to-go system introduced in June 2008, which gives unemployment benefits to non-EU nationals who agree to return home. However, this program had only recorded 11,660 applications by April 2010 (compared to the anticipated 87,000 applications) and only 8,451 immigrants actually returned home (Lopez et al. 2011). Furthermore, the fact that the overall stock of EaP migrants has not decreased as much as expected also suggests that the incentive programmers to foster return migration put in place by the Spanish government have not worked. Several factors may explain this, including: (i) the fear of return, which may be considered as a personal failure; (ii) the fact that some migrants have now their family, social and emotional network in Spain; (iii) a poor economic situation in their country of origin; and (iv) fear that re-entry would be difficult due to tough border control/legal restrictions ${ }^{15}$.

Despite the dramatic unemployment numbers, there are still some occupations which are difficult to fill. Each quarter the regional authorities publish a list of "difficult to cover occupations"16. Prior to 2008, it was hard to find workers to cover the large number of vacancies in the construction and the restoration sector. Nowadays, the uncovered vacancies are in the fishing and the maritime sector. Those jobs require technical skills to deal with sophisticated machines and availability to spend much time travelling (i.e. on board). 
In the long run, Spain will need immigrants to cover labor shortages because of emigration and an ageing population. As a result of the recession many skilled natives (i.e. engineers, business persons and architects) are leaving to find better job opportunities in Western Europe, the United States or the booming economies in Latin America. Analysts are not very optimistic about the recovery of the Spanish economy, thus most of those emigrant workers are not likely to return. In turn, skilled immigrants, with lower reservation wages, such as EaP migrants, are good candidates to cover those vacancies. In addition, the ageing population will increase the demand for elderly care services. The Spanish experience suggests that immigrants, and in particular women, will fill these vacancies, at least during their first years upon arriving in Spain.

Given the current situation of the Spanish economy, a liberalization of the immigration law is very unlikely to occur. However, the government should establish bilateral agreements with EaP countries to cover the anticipated labor demand shortages. For example, workers can be hired with a fix-term contract to fill labor shortages in the care sector. Some policies should also be implemented to replace Spanish skills migration. In this direction, permanent or high-incentive contracts should be offered to attract educated workers with technical degrees.

\section{Endnotes}

${ }^{1}$ The Eastern Partnership (EaP) is an initiative of the European Union intended to provide a venue for discussion of trade, economic strategy, travel agreements and other issues between the $\mathrm{EU}$ and its eastern neighbors.

${ }^{2}$ Note that since September 2012 there are some restrictions regarding the eligibility for health care coverage among immigrants. For example, immigrants without legal residence (i.e. illegal immigrants) are not covered.

${ }^{3}$ As is common practice in the research using this dataset, we only use the second quarter to avoid repeated observations. The LFS is carried out every quarter on a sample of around 60,000 households. Each quarter, one sixth of the sample is renewed. However, the dataset does not include a variable that allows identification of individuals along the six consecutive interviews.

${ }^{4}$ High-earning occupations are directors, managers, scientific technicians, professionals and academics. Middle-earning occupations include: technicians and support professions; accountancy, administrative and other office employees; and craftsperson and skilled workers in manufacturing and construction. Low-skilled occupations include workers in: catering, personal and protections services and sales; agriculture, livestock, forestry and fishing; installation and machinery operators and assemblers; and other elementary occupations.

${ }^{5}$ To be able to receive UI benefits in Spain you have to be registered in the Social Security records, under 65 years old, unemployed and have contributed to social security for at least 12 months (not necessarily consecutive).

${ }^{6}$ To have the legal status, immigrants were required to acquire a work and residency permit that restricted them to a particular activity and geographic area only for a year. In addition, immigrants were not granted any social benefits, despite paying social security taxes when employed. 
${ }^{7}$ For instance, in the 2000 amnesty, immigrants had to provide proof of one of the following: (i) residence since 1 June 1999; (ii) having held a work permit any time during the three-year period preceding 1 February 2000; (iii) being denied asylum before February 2000; (iv) having applied for any type of residence permit before 30 March 2000; or (v) family ties to legal residents or to individuals in any of the previous categories.

${ }^{8}$ State refers to the 17 Autonomous Community region.

${ }^{9}$ We cannot include housing, schooling or health-care benefits are these are not measured in the LFS.

${ }^{10}$ We refer the reader to Table 3 for the descriptive statistics of the variables in the analysis.

${ }^{11}$ We obtain the estimate of 12 percentage points by adding 0.32 and -0.20 .

${ }^{12}$ See the estimated coefficient on the interaction of years since migration (YSM and $\mathrm{YSM}^{\wedge} 2$ ) with the EaP indicator. An alternative explanation proposed by Borjas is that more recent cohorts are worse than earlier ones. However, as this was a wave of mass migration within just a few years, this critique is probably of lesser importance in this case.

${ }^{13}$ Rodríguez-Planas (2013) includes the following benefits as cash-welfare : (i) unemployment benefits; (ii) disability pensions; (iii) survivor's pension; (iv) family allowance; and (v) other social programs.

${ }^{14}$ According to the raw data, immigrants are more likely to visit the family doctor and go to the emergency room than natives. Similar results are found by Jiménez et al. 2009.

${ }^{15}$ Ukraine, the source country of the majority of EaP immigrants to Spain, is immerse in a deep economic recession due to a weak external demand and delays in policy adjustments.

${ }^{16} \mathrm{http} / / /$ www.sepe.es/contenido/empleo_formacion/catalogo_ocupaciones_dc/pdf/ CatalogoOcupacionesDificilCobertura.pdf.

\section{Competing interests}

The IZA Journal of European Labor Studies is committed to the IZA Guiding Principles of Research Integrity. The authors declare that they have observed these principles.

\section{Acknowledgements}

This study was conducted under the project entitled "Costs and Benefits of Labour Mobility between the EU and the Eastern Partnership Countries" for the European Commission (Contract No. 2011/270-312, tender procedure EuropeAid/130215/C/SER/Multi). The European Commission retains ownership of the materials contained herein. Responsible editor: Martin Kahanec

\section{Author details}

${ }^{1}$ University of Barcelona (UB), Barcelona, Spain. ${ }^{2}$ Institut d'Anàlisi Econòmica (IAE-CSIC), Bellaterra, Spain. ${ }^{3}$ Institute for Labor Studies (IZA), Bonn, Germany.

\section{References}

Alcobendas M, Rodríguez-Planas N (2009) Occupational Assimilation After a Recent Immigration Boom. IZA discussion paper No. 4394, Bonn, Germany

Amuedo-Dorantes C, de la Rica S (2005) Immigrants' Responsiveness to Labor Market Conditions and its Implications on Regional Disparities: Evidence from Spain. IZA Discussion Paper No. 1557, Bonn, Germany

Amuedo-Dorantes C, De la Rica S (2007) Labor market assimilation in Spain. Br J Ind Relat 45(2):257-284. 0007-1080

Amuedo-Dorantes C, De la Rica S (2008) Does Immigration Raise Natives' Income? National and Regional Evidence from Spain. IZA Discussion Paper No. 3486, Bonn, Germany

Amuedo-Dorantes C, de la Rica S (2013) The immigration surplus and the substitutability of immigrants and native labor: evidence from Spain. Empirical Economics Vol 44(2):945-958 
Andrés J (2009) España y los Desequilibrios Globales, Libro Electrónico Sociedad Abierta-Fedea: "La Crisis de la Economía Española: lecciones y propuestas. FEDEA, Madrid, España

Carrasco R, Jimeno JF, Ortega AC (2008) The effect of immigration on the employment opportunities of native-born workers: some evidence for Spain. J Popul Econ 21:627-648

Castles S, Miller MJ (2003) "The Age of Migration".International Population Movements in the Modern World. Palgrave, Hampshire and New York

de la Rica S (2009) In: Kahanec M, Zimmermann KF, EU Labor Markets after Post-Enlargement Migration, Berlin, et al. (ed) The Experience of Spain with the Inflows of New Labor Migration, pp 131-144

Dolado J, Vázquez P (2007) Los Efectos Económicos y las Políticas de la Inmigración: Panorámica y Reflexiones. FEDEA Working Paper, Madrid, Spain

Farré L, González L, Ortega F (2011) Immigration, Family responsibilities and the labor supply of skilled native women. BEJ Econ Anal Pol 11(1):1-46

Fernández C, Ortega C (2008) Labor market assimilation of immigrants in Spain: employment at the expense of Bad Job-matches? Span Econ Rev 10(2):83-107

Ferrera M (1996) The "southern model" of welfare in social Europe. J Eur Soc Pol 6(1):17-37

Flaquer L (2000) Family Policy and Welfare State in Southern Europe. Institut de Ciències Polítiques I Socials, WP No, 185, Barcelona, Spain

Garicano L (2008) La Transición Económica Pendiente. Expansión, Madrid, España. Expansión, 05-12-2008

Gianmarco IP, Ottaviano, Giovanni P (2012) Rethinking the Effects of Immigration on Wages. J European Econ Assoc vol. 10(1):152-197. 02

Guillén A (1997) "Welfare State Development in Spain: A Historical and Explanatory Approach" in Mire Florence Conference, Comparing Social Welfare Systems in Southern Europe vol. 3/1997. Mire, Paris, pp 67-91

Izquierdo M, Lacuesta A, Vegas R (2009) Assimilation of immigrants in spain: a longitudinal analysis. Labor Econ 16(6):669-678

Jiménez S, Jorgensen N, Labeaga JM (2009) "Inmigración y Demanda de Servicios Sanitarios". In Efectos Económicos de la Inmigración en España. Monografías FEDEA, Madrid, Spain

Lopez, Maria P, Davis, Roxana A (2011) Immigration Law Spanish-Style II: A Study of Spain's Voluntary Immigrant Return Plan and Circular Migration (November 29, 2011). In: 25 Temple International \& Comparative Law Journal 79 (2011). Loyola University New Orleans College of Law Research Paper No. 2011-07. Available at SSRN: http://ssrn.com/ abstract $=1966265$

Muñoz De Bustillo R, Antón JI (2009) Immigration and Social Benefits in a Mediterranean Welfare State: The Case of Spain. MPRA Paper No. 13849, Munich, Germany

Rodríguez-Planas N (2012) Wage and occupational assimilation by skill level. Migration policy lessons from Spain. IZA J Eur Labor Studies 1:8. 31 December 2012

Rodríguez-Planas N (2013) Determinants of Immigrant's cash-welfare benefit intake in Spain. Int J Manpow 34(2):167-168

Salinas Jiménez J, Santín González D (2010) Los efectos presupuestarios de la inmigración en el sistema educativo español. Presupuesto y Gasto Público 61/2010. Secretaría General de Presupuestos y Gastos 2010, Instituto de Estudios Fiscales, Madrid, Spain, pp 133-157

Solé C (2004) Immigration policies in southern Europe. J Ethn Migr Stud 30(6):1209-1221

10.1186/2193-9012-3-1

Cite this article as: Farré and Rodríguez-Planas: Immigrants from eastern partnership (EaP) countries in Spain. IZA

Journal of European Labor Studies 2014, 3:1

\section{Submit your manuscript to a SpringerOpen ${ }^{\circ}$ journal and benefit from:}

- Convenient online submission

- Rigorous peer review

- Immediate publication on acceptance

- Open access: articles freely available online

- High visibility within the field

- Retaining the copyright to your article

Submit your next manuscript at $\boldsymbol{~ s p r i n g e r o p e n . c o m ~}$ 